\title{
Business Models for Open Innovation: From Collaboration to Incorporation
}

\author{
Francesca Michelino ${ }^{1}$, Antonello Cammarano ${ }^{2}$, Emilia Lamberti ${ }^{3}$ and \\ Mauro Caputo ${ }^{4}$ \\ ${ }^{1,2,4}$ Department of Industrial Engineering, University of Salerno, \\ Fisciano, Italy \\ ${ }^{3}$ Department of Enterprise Engineering, University of Rome "Tor Vergata", \\ Roma, Italy
}

Correspondence should be addressed to: Emilia Lamberti; emilia.lamberti@uniroma2.it

Received date: 11 February 2014; Accepted date: 29 Juin 2014; Published date: 24 March 2015

Academic Editor: Chandana Unnithan

Copyright (C) 2015. Francesca Michelino, Antonello Cammarano, Emilia Lamberti and Mauro Caputo. Distributed under Creative Commons CC-BY 4.0

\begin{abstract}
The paper describes five open innovation business models - collaboration, outsourcing, licensing, trading and incorporation - defined on the basis of open revenues and costs, new investments and divestments in intangibles. A sample of 271 companies from biopharmaceutical and technology hardware \& equipment industries is investigated, and their annual reports for the three years period 2010-2012 are analysed. Results show that for biotech companies open innovation represents a characteristic activity, with most of them having high values of revenues deriving from joint development projects. On the other side, for pharmaceutical firms open innovation is somehow ancillary: even if most open innovation activities are widespread, their values are not really significant if compared to the total business volume. As to the technology hardware \& equipment industry, the use of spin-ins as a mean for incorporating external knowledge is the most frequent open strategy. This work contributes to the research on open innovation by defining the business models that R\&D intense companies may adopt to foster open innovation. From a managerial point of view, the framework can be used by companies for assessing the status of their own open strategies, also allowing the benchmarking with competitors.
\end{abstract}

Keywords: Open innovation; Business model; Bio-pharmaceutical; Technology hardware \& equipment

\section{Introduction}

The paper aims at analysing the business models adopted by R\&D intense companies in order to embrace the open innovation (OI) paradigm.
Since the definition of the paradigm, OI models have been largely investigated by scholars through the definition of all the activities adopted by firms to open up their innovation processes. Yet, even if Chesbrough (2003) stressed the role OI has 
in influencing the business of companies in monetary terms, this dimension was neglected by almost all the contributions. In order to fill such a gap, we adopt an accounting perspective for analysing the open behaviours of firms, by investigating the operational and financial open transactions in both inbound and outbound processes. The research question we aim at answering is: how do companies implement OI within their business models, in order to incorporate external technologies and exploit internal innovative outputs on external markets. In order to define the OI business models of companies we analysed OI transactions through accounting data of 271 world top R\&D spending companies in biopharmaceutical and technology hardware $\&$ equipment industries for the three years period 2010-2012, for a total of 813 consolidated annual reports analysed. Both the framework applicability and its explicative power and usefulness were validated.

In what follows, after reviewing literature contributions on OI adoption models, methodology is presented and applied to the selected sample, results are discussed and conclusions will close the work.

\section{Literature Review}

The theme of how companies are implementing OI is largely investigated in literature and a number of different $\mathrm{OI}$ business models are described.

The most acknowledged taxonomy distinguishes inbound from outbound OI (Gassmann and Enkel, 2004) - the former addressed to enrich the knowledge base of companies through relationships with external sources of knowledge, the latter to bring internal ideas to external markets and different scholars adopted the inbound vs. outbound approach to define OI business models.

Podmetina et al. (2011) classified companies in nine clusters, from "no buy, no sell", i.e. a total closed behaviour, to "active buy, active sell" when both inbound and outbound activities are relevant. Gianiodis et al. (2010) defined four models for open firms: "innovation seekers" who buy technology from outside, "innovation providers" selling their own technology, "intermediaries" between the first two categories and "open innovators" being capable to act as both innovation seekers to fill technology gaps and innovation providers to divest a particular technological trajectory. Dahlander and Gann (2010) add to the inbound vs. outbound dimension the pecuniary vs. nonpecuniary nature of $\mathrm{OI}$ activities, defining two forms of inbound innovation acquiring and sourcing - and two types of outbound innovation - selling and revealing.

Several contributions focus on the practices that companies adopt for pursuing OI (Bianchi et al., 2011; Hung and Chiang, 2010; Santamaria et al., 2010; Schroll and Mild, 2011; van de Vrande et al., 2009): within inbound activities we have alliances, networking, use of technology consultants, R\&D cooperation, IP in-licensing, R\&D outsourcing, involvement of external parties and purchase of scientific services; whilst outbound practices can be alliances, supply of scientific services, IP out-licensing and venturing. Tranekjer and Knundsen (2012) add to the analysis of inbound and outbound practices also the internal mechanisms fostering $\mathrm{OI}$, such as supporting employees working on own ideas and entrepreneurial activities within the company. Also Cheng and Huizingh (2014) add one dimension, by investigating coupled practices combining importing and exporting mechanisms.

Yet, a large part of contributions in literature focus only on inbound processes, neglecting the role of outbound OI.

After the definition of Laursen and Salter (2006), different studies outlined open models by analysing OI breadth and depth, the former being the number of external sources of knowledge, the latter the degree of use of such sources. Keupp and Gassmann (2009) identified three clusters of open companies: "professionals" collaborating both broadly and deeply, "explorers" with a medium to large breadth and a medium degree of depth, "scouts" with a medium to large breadth and a low degree of depth. Idrissia et al. (2012) define "open" the companies with high breadth and depth, "user" the companies with high breadth and low depth, "interactive" the 
firms with low breadth and high depth. Lazzarotti and Manzini (2009), even if adopting a breadth vs. depth perspective, provide different definitions of the two terms: the former being the number of different typologies of partners, the latter defined as the different innovation process phases in which the company opens to external contributions. After these definitions, the authors find three OI models: "specialized collaborators" characterized by high breadth and low depth, "integrated collaborators" with low breadth and high depth and "open innovators" characterized by high levels of both.

A different approach for investigating inbound models is distinguishing between collaboration and outsourcing activities. Teirlinck and Spithoven (2008) outline that "co-developing innovators" collaborating with innovation partners are more open than "outsourcing innovators" who acquire R\&D services from third parties. In a following paper, Teirlinck and Poelmans (2012) add a third model which combines the previous two defining an "integrated networking strategy". Two different dimensions of inbound OI are analysed by Barge-Gil (2010): the authorship of innovation and the relative importance of internal sources of innovation over external ones. Thus, "semi-open innovators" are characterized by innovations which were mainly internally developed with only some external contributions and higher importance of internal versus external sources is found, while "open innovators" develop innovations mainly through collaboration or outsourcing and rely on at least one external source more important than the internal ones. Other scholars focus on inbound practices such as external idea and knowledge sourcing and external R\&D
(Kim and Park, 2010) or technology scouting and sourcing and horizontal and vertical technology collaboration (Parida et al., 2012). Spithoven (2013) incorporates inbound mechanisms such as knowledge spillovers and research cooperation with practices for in-house knowledge strategic protection.

Regardless the focus on either both inbound and outbound or only inbound, all the contributions analysed do not use pecuniary data to describe the OI adoption models: by investigating whether a company performs or not different open activities, they neglect the impact that such activities have on its business, in terms of revenues, costs, new investments or divestments. We contribute to the existing literature by suggesting a new taxonomy of OI models based on the monetary flows linked to open activities.

\section{Methodological Framework}

From the analysis of companies' annual reports, four kinds of transactions can be found in the OI market related to inbound vs. outbound processes having an operational vs. financial nature: costs and revenues are respectively inbound and outbound operational transactions disclosed in the income statement of companies, while additions and disposals are the new investments and divestments in intangibles, disclosed in the balance sheet, which respectively represent inbound and outbound financial transactions. A comprehensive description of our measurement framework for OI can be found in Michelino et al. (2014), where the openness of a company is summarized by comparing open costs, revenues, intangible investments (additions) and divestments (disposals) to its total costs, revenues and intangibles:

$$
\text { openness }=\sqrt{\frac{1}{4}\left[\left(\frac{\text { open costs }}{\text { total } R \& D \text { and IP costs }}\right)^{2}+\left(\frac{\text { open revenues }}{\text { total revenues }}\right)^{2}+\left(\frac{\text { additions }}{\text { total intangibles }}\right)^{2}+\left(\frac{\text { disposals }}{\text { total intangibles }}\right)^{2}\right]}
$$

In this paper we are focusing on the different strategies for pursuing OI and we can distinguish five broad categories of open transactions:
1. collaborative costs (CC) and revenues (CR), referring to cooperations with innovation partners within joint R\&D programs; 
2. costs from R\&D outsourcing (OC) and revenues from performing R\&D on behalf of third parties (OR), including grants received from the government for $R \& D$ activities;

3. in-licensing costs (LC) and outlicensing revenues (LR);

4. additions (SA) and disposals (D) of innovation-related intangibles in separate acquisitions;

5. additions of innovation-related intangibles within business combinations (BA).

As to operational transactions, three different underlying logics can be defined, from an increase of knowledge for both the parties, through the delivery of a black box, to the concession of a right without the transfer of ownership. As regards financial transactions, two different logics can be defined as well. When a separate acquisition occurs, a focalized interest on an intangible, e.g. a specific patent, can be outlined. On the contrary, within business combinations, mergers and acquisitions (BCMAs), the acquiring company can be interested not only on the recognized intangibles, but also in the skills of human resources working in the acquired firm. Such a distinction makes it important to consider the goodwill arising from BCMAs as a proxy for intellectual capital, consistently with literature (Boekestein, 2009; Brännström et al., 2009). Thus, five business models for OI can be defined: collaboration, outsourcing, licensing, trading and incorporation (Table 1). The first four have both, inbound and outbound components, while the fifth can be defined only inbound since, when an incorporation occurs, the incorporated company does not exist anymore and no annual report is written off for it.

Table 1: Open innovation business models

\begin{tabular}{|c|c|c|}
\hline Model & $\begin{array}{c}\text { Inbound } \\
\text { components }\end{array}$ & $\begin{array}{c}\text { Outbound } \\
\text { components }\end{array}$ \\
\hline Collaboration & collaboration costs & collaboration revenues \\
Outsourcing & outsourcing costs & outsourcing revenues \\
Licensing & licensing costs & licensing revenues \\
Trading & separate additions & disposals \\
Incorporation & BCMAs additions & - \\
\hline
\end{tabular}

For each component we can define intensity as the degree of importance for each company, if compared to its total volume of business, i.e. total R\&D and IP costs for open costs, total revenues for open revenues and total intangibles for additions and disposals.

All the OI components are calculated starting from annual reports and thus refer to one fiscal year; yet, if the phenomenon is observed over a longer period of time, we can also analyse whether the components are continuously present in the financial statements of companies or not. Hence, for each component we define the variable time as the number of years in which it is reported in the annual report of a company.

The intensity-time analysis leads to the definition of four categories of business models for each company:
- if a component is both intense and continuous over time, we can define it characteristic since it strongly characterizes the business of the company all over a long period of time;

- if it is continuous over time but not intense, it can be defined ancillary since the company constantly performs the activity, even if it is not very relevant if compared to its total business;

- if it is intense but not continuous over time, we can define it exceptional since it strongly but discontinuously characterizes the business of the company;

- finally, if it is neither intense nor continuous over time it can be defined negligible.

A third variable can be used to define the pervasiveness of a business model within a 
given set of companies, e.g. an industry or a segment: frequency. If we have a sample of $N$ companies with $n \leq N$ of them having a specific item, we can define its frequency as:

$$
\text { frequency }=\frac{n}{N}
$$

Thus, given a set of companies, we can define the mean values of intensity and time and compare them to the frequency, so that for each of the four aforementioned categories we can separate the common behaviours from the uncommon ones. For example, if the mean values of intensity and time are high and frequency is high, the model is characteristic for the whole sample, whereas, if the frequency is low it is characteristic only for a niche of companies.

By multiplying the three variables, a synthetic measure of the relevance of each model can be defined; in particular, if we are analysing open business models over a period of $\mathrm{Y}$ years, a percentage indicator can be calculated as:

$$
\text { relevance }=\text { intensity } \cdot \frac{\text { time }}{Y} \cdot \text { frequency }
$$

The suggested models were analysed for a sample of 271 companies drawn from The EU Industrial R\&D Investment Scoreboard, which reports the top R\&D spending firms worldwide. Consolidated annual reports data for the period 2010-2012 were analysed, for a total of 813 statistical units. Two industries were selected: biopharmaceutical and technology hardware \& equipment; according to ICB codes, the former is divided into biotechnology (BIO) and pharmaceutical (PH) segments, the latter in computer hardware \& office equipment (HWOE), semiconductors (SC) and telecommunications equipment (TLCE) segments. Descriptive statistics are provided in Table 2, while in Tables 3 and 4 the mean values of intensity, time and frequency for each segment are reported (mean values for intensity and time were calculated only for those companies with a non-zero value). In Figures 1 to 5 a positioning map is reported for each segment: $\mathrm{x}$ and $\mathrm{y}$ axes respectively represent time and intensity, while the frequency is defined by the dimension of the bubble.

Table 2: Sample description by segment

\begin{tabular}{|c|c|c|c|c|}
\hline Segment & $\begin{array}{c}\text { No. of } \\
\text { companies }\end{array}$ & $\begin{array}{c}\text { Average no. } \\
\text { of } \\
\text { employees }\end{array}$ & $\begin{array}{c}\text { Average } \\
\text { R\&D/revenues }\end{array}$ & $\begin{array}{c}\text { Average } \\
\text { opennes } \\
\text { s }\end{array}$ \\
\hline BIO & 58 & 1,458 & $24.7 \%$ & $34.7 \%$ \\
\hline PH & 68 & 18,519 & $16.0 \%$ & $17.0 \%$ \\
\hline HWOE & 29 & 44,047 & $3.4 \%$ & $10.8 \%$ \\
\hline SC & 70 & 8,619 & $15.9 \%$ & $13.1 \%$ \\
\hline TLCE & 46 & 17,605 & $13.3 \%$ & $10.8 \%$ \\
\hline
\end{tabular}


Table 3: Intensity, time and frequency of inbound activities by segment

\begin{tabular}{|c|c|c|c|c|c|c|c|c|c|c|c|c|c|c|c|}
\hline \multirow[t]{2}{*}{ Segment } & \multicolumn{3}{|c|}{$\begin{array}{c}\text { Collaboration } \\
\text { costs }\end{array}$} & \multicolumn{3}{|c|}{$\begin{array}{c}\text { Outsourcing } \\
\text { costs }\end{array}$} & \multicolumn{3}{|c|}{$\begin{array}{l}\text { Licensing } \\
\text { costs }\end{array}$} & \multicolumn{3}{|c|}{$\begin{array}{c}\text { Separate } \\
\text { additions }\end{array}$} & \multicolumn{3}{|c|}{$\begin{array}{c}\text { BCMAs } \\
\text { additions }\end{array}$} \\
\hline & int. & time & freq. & int. & time & freq. & int. & time & freq. & int. & time & freq. & int. & time & freq. \\
\hline $\mathrm{IO}$ & $14 \%$ & 2.5 & $34 \%$ & $39 \%$ & 2.5 & $38 \%$ & $7 \%$ & 2.4 & $33 \%$ & $6 \%$ & 2.0 & $53 \%$ & $40 \%$ & 1.5 & $45 \%$ \\
\hline $\mathrm{PH}$ & $5 \%$ & 2.2 & $35 \%$ & $22 \%$ & 2.1 & $26 \%$ & $16 \%$ & 2.5 & $28 \%$ & $5 \%$ & 2.5 & $81 \%$ & $18 \%$ & 2.1 & $59 \%$ \\
\hline HWOE & $3 \%$ & 3.0 & $3 \%$ & $2 \%$ & 1.3 & $10 \%$ & $0 \%$ & 0.0 & $0 \%$ & $6 \%$ & 2.0 & $86 \%$ & $22 \%$ & 2.2 & $90 \%$ \\
\hline $\mathrm{SC}$ & $8 \%$ & 3.0 & $4 \%$ & $11 \%$ & 3.0 & $7 \%$ & $11 \%$ & 2.1 & $11 \%$ & $9 \%$ & 2.2 & $76 \%$ & $28 \%$ & 1.8 & $86 \%$ \\
\hline TLCE & $0 \%$ & 0.0 & $0 \%$ & $28 \%$ & 2.7 & $7 \%$ & $2 \%$ & 2.0 & $4 \%$ & $7 \%$ & 2.0 & $65 \%$ & $27 \%$ & 1.8 & $80 \%$ \\
\hline
\end{tabular}

Table 4: Intensity, time and frequency of outbound activities by segment

\begin{tabular}{|c|c|c|c|c|c|c|c|c|c|c|c|c|}
\hline \multirow{2}{*}{ Segment } & \multicolumn{2}{|c|}{$\begin{array}{c}\text { Collaboration } \\
\text { revenues }\end{array}$} & \multicolumn{3}{c|}{$\begin{array}{c}\text { Outsourcing } \\
\text { revenues }\end{array}$} & \multicolumn{3}{c|}{$\begin{array}{c}\text { Licensing } \\
\text { revenues }\end{array}$} & \multicolumn{3}{c|}{ Disposals } \\
\cline { 2 - 14 } & int. & time & freq. & int. & time & freq. & int. & time & freq. & int. & time & freq. \\
\hline $\mathrm{BIO}$ & $43 \%$ & 2.8 & $81 \%$ & $19 \%$ & 2.6 & $59 \%$ & $25 \%$ & 2.6 & $62 \%$ & $9 \%$ & 1.4 & $29 \%$ \\
\hline $\mathrm{PH}$ & $23 \%$ & 2.6 & $50 \%$ & $4 \%$ & 2.3 & $47 \%$ & $14 \%$ & 2.5 & $57 \%$ & $2 \%$ & 2.1 & $65 \%$ \\
\hline $\mathrm{HWOE}$ & $0 \%$ & 2.0 & $10 \%$ & $0 \%$ & 2.5 & $59 \%$ & $13 \%$ & 3.0 & $14 \%$ & $5 \%$ & 2.1 & $69 \%$ \\
\hline $\mathrm{SC}$ & $1 \%$ & 3.0 & $7 \%$ & $1 \%$ & 2.5 & $59 \%$ & $28 \%$ & 2.8 & $21 \%$ & $7 \%$ & 1.7 & $57 \%$ \\
\hline $\mathrm{TLCE}$ & $0 \%$ & 0.0 & $0 \%$ & $1 \%$ & 2.7 & $63 \%$ & $12 \%$ & 2.6 & $20 \%$ & $8 \%$ & 1.7 & $63 \%$ \\
\hline
\end{tabular}

The biotechnology segment is characterized by the highest values of openness. Collaboration revenues and outsourcing costs are characteristic activities since they are both intense and continuous over time. Further, licensing and outsourcing revenues as well as collaboration and licensing costs can be considered ancillary given their lower intensity but still high continuity over time. Actually, in this segment OI strongly characterizes the income statement of the companies. As a matter of fact, biotech companies, being still in the development phase, do not sell products, but rather enter into agreements with other biopharmaceutical companies for joint $R \& D$ projects and earn from licensing their intellectual property. Thus, most part of the EBIT of companies derives from OI transactions. In particular, OI revenues are widespread in more than half of the companies of the segment, while OI costs can be detected in about one third of the sample.

On the contrary, trading and incorporation strategies are less continuous over time. In particular, incorporation is exceptional since, even if spin-ins are seldom performed by biotech companies, their influence on the total business is very high, while trading is negligible since the separate acquisition or disposal of intangibles does not increase or decrease the total value of intangibles in a significant way. Additions are more widespread than disposals all over the segment, with $45 \%$ to $53 \%$ companies performing the former and $29 \%$ the latter. 


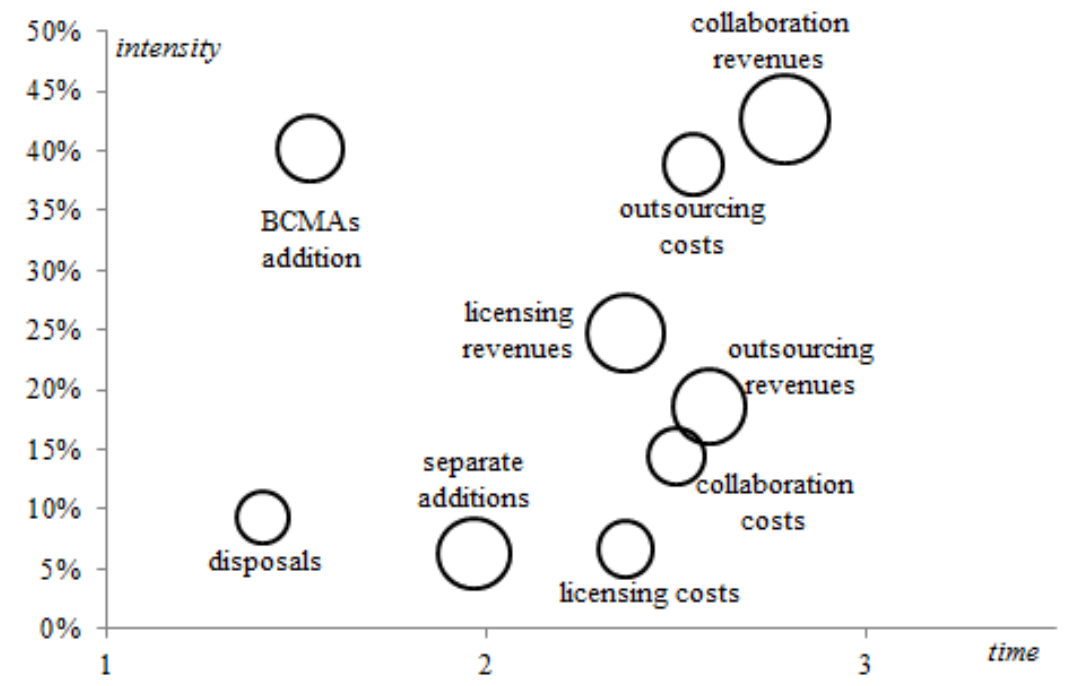

Figure 1: Open innovation strategies for biotechnology companies

OI is much less characterizing the pharmaceutical segment, if compared to the biotechnology one. Actually, even if all OI activities are quite continuous over time, their relevance is always limited when compared to the total volume of their business, so that the whole OI phenomenon can be defined ancillary for pharmaceutical companies. Actually, while biotech firms are typically focused on R\&D, pharmaceutical companies have the commercialization of drugs as the core business and OI is only a complementary activity. Further, even if the open transactions in the segment can be relevant, their intensity, when compared to

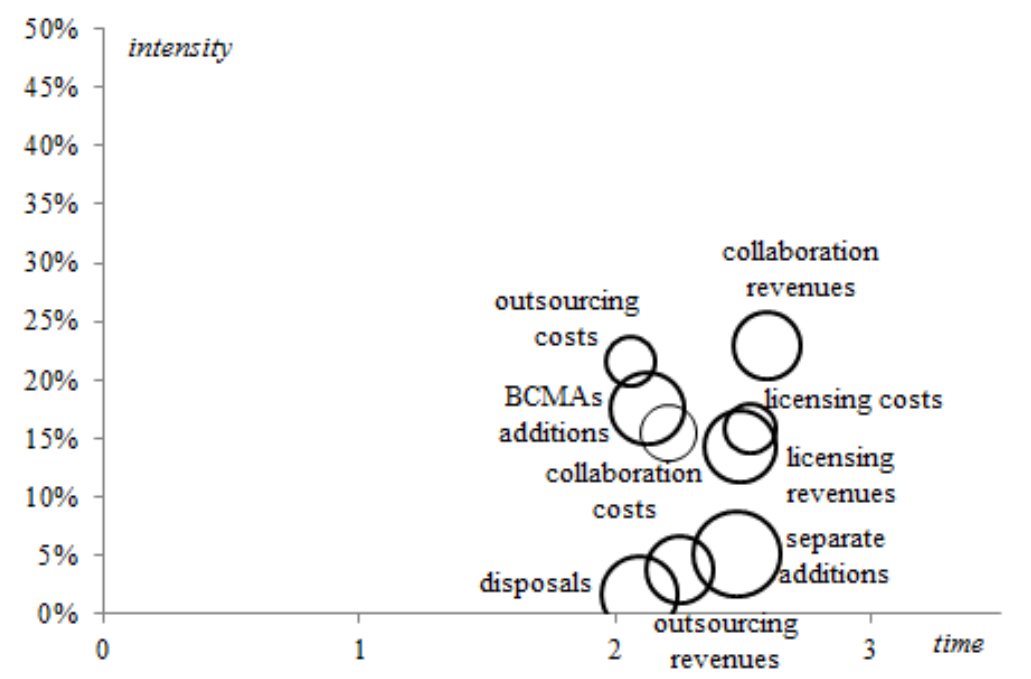

Figure 2: Open innovation strategies for pharmaceutical companies the total business of companies, is typically low, given their large dimension.

Just like biotech firms, the most intense and continuous activity for pharmaceutical companies is outbound collaboration, which is also quite frequent in the segment (50\%), but the most frequent strategy in the sample, even if with a low intensity, is trading, with $65 \%$ companies selling and $81 \%$ acquiring intangibles. In particular, companies in the pharmaceutical segment show a dynamic management of their brand portfolio, by acquiring and selling trademarks. 


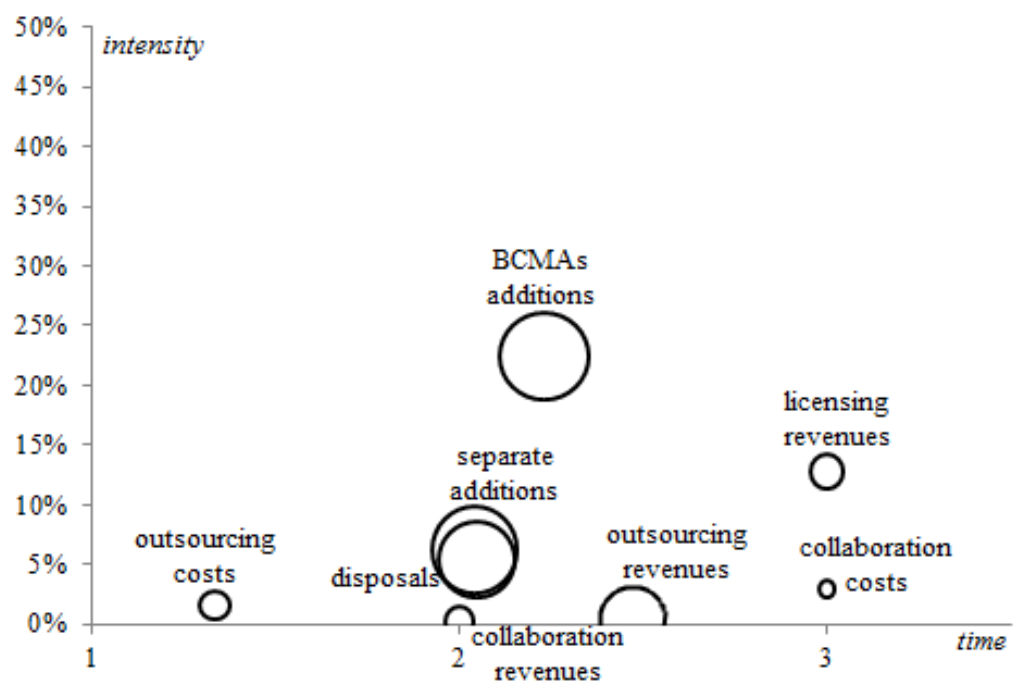

Figure 3: Open innovation strategies for computer HW \& office equipment companies

Companies in the technology hardware \& equipment industry are less open than biopharmaceutical ones. Most open activities are either ancillary or negligible, i.e. the value of open transactions is small if compared to the total business of companies. In all the three segments of the industry, most open revenues and costs are quite infrequent denoting niche behaviours. The only exception is given by outsourcing revenues which can be detected in more than $50 \%$ of the companies for more than 2,5 years over 3 , even if their intensity is close to zero; such revenues are linked to $R \& D$ tax credits.

For all the companies in the industry, the most frequent open strategy is incorporation of other companies, with BCMAs additions frequency ranging from $80 \%$ to $90 \%$.

Two characteristic models can be detected for a niche of companies: outbound licensing for semiconductors firms and inbound outsourcing for telecommunications equipment ones. The former is a characteristic of companies owning a dominant design in semiconductors technologies and licensing it to other firms; the latter can be explained through IT modularity, with companies outsourcing the development of one or more modules to third parties.

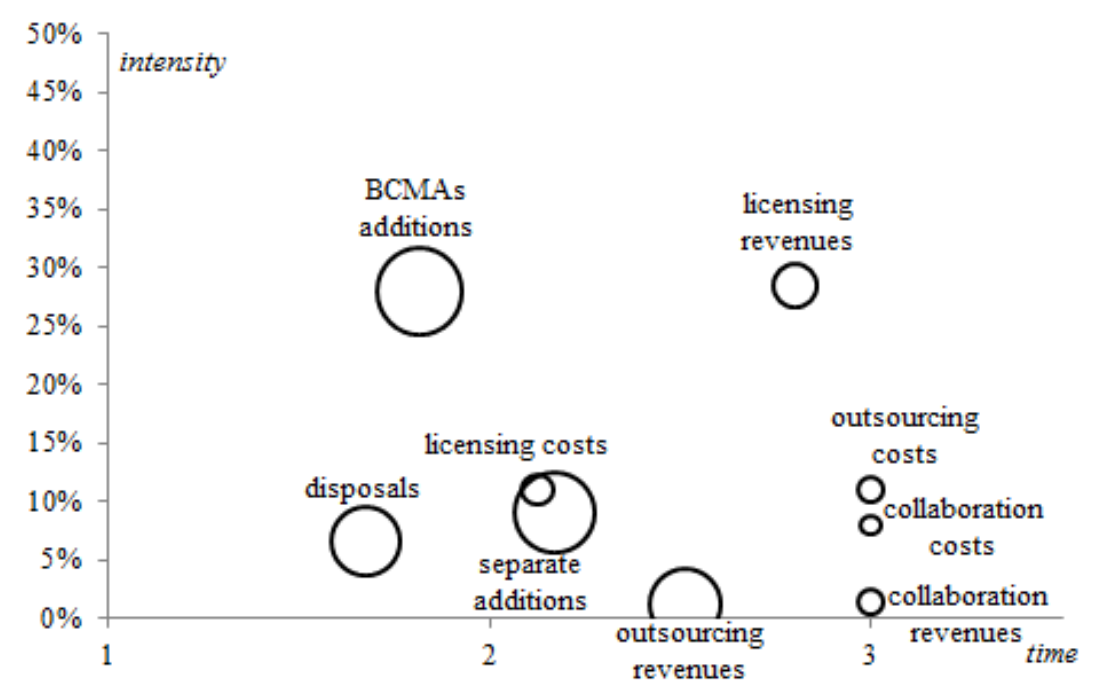

Figure 4: Open innovation strategies for semiconductors companies 


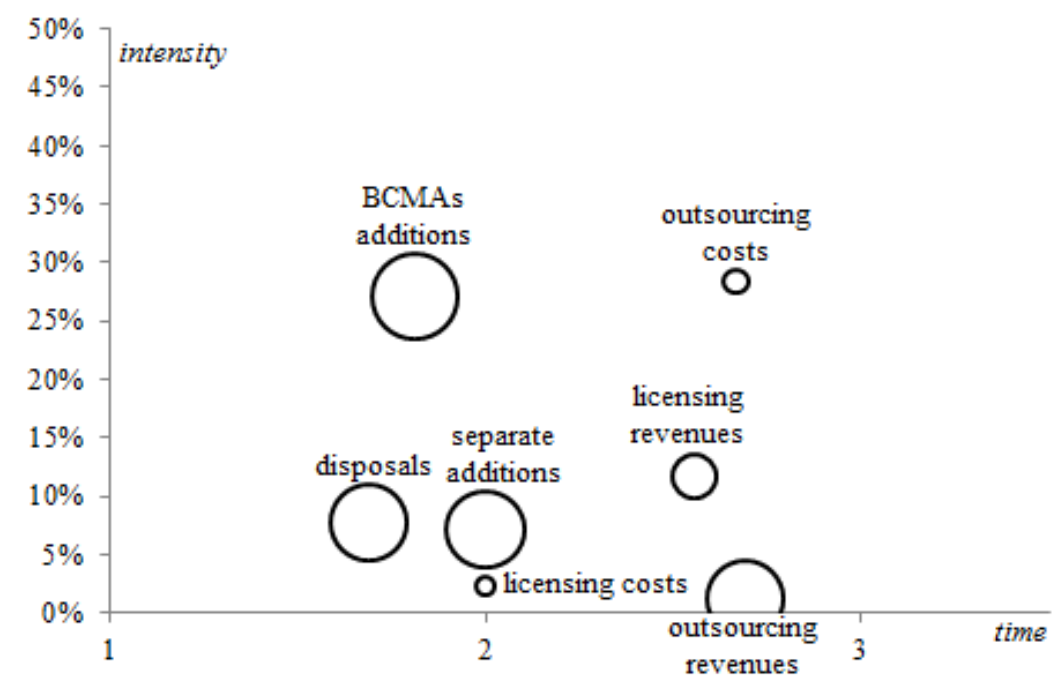

Figure 5: Open innovation strategies for telecommunications equipment companies

The results obtained since now can be summarized by the definition of the relevance of each component for each segment (Table 5):

- the most relevant strategy for biotech companies is outbound collaboration, followed by outbound licensing and inbound outsourcing;
- in the pharmaceutical segment, outbound collaboration is followed by incorporation;

- in all the segments of the technology hardware \& equipment industry, incorporation is the primary and most relevant strategy.

Table 5: Relevance of open models by segment

\begin{tabular}{|c|c|c|c|c|c|c|c|c|c|}
\hline \multirow{2}{*}{ Segment } & \multicolumn{2}{|c|}{ Collaboration } & \multicolumn{2}{c|}{ Outsourcing } & \multicolumn{2}{c|}{ Licensing } & \multicolumn{2}{c|}{ Trading } & Incorporation \\
\cline { 2 - 10 } & $\begin{array}{c}\text { inbound } \\
\text { (CC) }\end{array}$ & $\begin{array}{c}\text { outbound } \\
(\mathrm{CR})\end{array}$ & $\begin{array}{c}\text { inbound } \\
(\mathrm{OC})\end{array}$ & $\begin{array}{c}\text { outbound } \\
(\mathrm{OR})\end{array}$ & $\begin{array}{c}\text { inbound } \\
(\mathrm{LC})\end{array}$ & $\begin{array}{c}\text { outbound } \\
(\mathrm{LR})\end{array}$ & $\begin{array}{c}\text { inbound } \\
(\mathrm{SA})\end{array}$ & $\begin{array}{c}\text { outbound } \\
(\mathrm{D})\end{array}$ & $\begin{array}{c}\text { inbound } \\
(\mathrm{BA})\end{array}$ \\
\hline $\mathrm{BIO}$ & $4.1 \%$ & $32.1 \%$ & $12.5 \%$ & $9.4 \%$ & $1.7 \%$ & $13.3 \%$ & $2.2 \%$ & $1.3 \%$ & $9.2 \%$ \\
\hline $\mathrm{PH}$ & $4.0 \%$ & $9.9 \%$ & $3.9 \%$ & $1.3 \%$ & $3.7 \%$ & $6.8 \%$ & $3.4 \%$ & $0.7 \%$ & $7.3 \%$ \\
\hline $\mathrm{HWOE}$ & $0.1 \%$ & $0.0 \%$ & $0.1 \%$ & $0.2 \%$ & $0.0 \%$ & $1.8 \%$ & $3.6 \%$ & $2.5 \%$ & $15.0 \%$ \\
\hline $\mathrm{SC}$ & $0.3 \%$ & $0.1 \%$ & $0.8 \%$ & $0.5 \%$ & $0.9 \%$ & $5.7 \%$ & $5.0 \%$ & $2.1 \%$ & $14.5 \%$ \\
\hline $\mathrm{TLCE}$ & $0.0 \%$ & $0.0 \%$ & $1.6 \%$ & $0.7 \%$ & $0.1 \%$ & $2.0 \%$ & $3.1 \%$ & $2.7 \%$ & $13.2 \%$ \\
\hline
\end{tabular}

Such findings were also confirmed through regression analyses performed using the intensity values of the different components as explicating variables for openness: using a stepwise method we can define the components which better explain openness for each segment by analysing their entry order.
In particular, we considered the regression models where the adjusted R-square reached a value equal or greater than 0.8 (Table 6). In each segment a different definition of OI can be obtained according to the open activities which are more relevant for the companies in the segment itself:

$$
\begin{gathered}
\text { openness }(B I O)=0.070+0.462 \mathrm{CR}+0.438 \mathrm{LR}+0.438 \mathrm{OR}+0.325 \mathrm{BA}+\varepsilon_{\mathrm{BIO}} \\
\text { openness }(P H)=0.044+0.497 \mathrm{CR}+0.487 \mathrm{LR}+0.396 \mathrm{BA}+0.391 \mathrm{LC}+\varepsilon_{\mathrm{PH}} \\
\text { openness }(H W O E)=0.019+0.484 \mathrm{BA}+0.456 \mathrm{SA}+\varepsilon_{\mathrm{HWOE}} \\
\text { openness }(S C)=0.021+0.441 \mathrm{BA}+0.375 \mathrm{LR}+0.491 \mathrm{SA}+\varepsilon_{\mathrm{SC}}
\end{gathered}
$$




$$
\text { openness }(T L C E)=0.027+0.471 \mathrm{BA}+0.445 \mathrm{D}+0.418 \mathrm{OC}+\varepsilon_{\mathrm{TLCE}}
$$

Where $\varepsilon_{i}$ is the error of the regression model.

Table 6: Synthesis of regression models - dependent variable: openness

\begin{tabular}{|c|c|c|c|c|c|c|c|c|c|c|c|}
\hline \multirow[b]{2}{*}{ Segment } & \multirow{2}{*}{$\begin{array}{l}\text { Adjusted } \\
\text { R-square }\end{array}$} & \multirow{2}{*}{$\begin{array}{l}\text { Std. error } \\
\text { of the est. }\end{array}$} & \multicolumn{2}{|c|}{ Mean of squares } & \multirow[b]{2}{*}{$\mathbf{F}$} & \multirow[b]{2}{*}{ Sig. } & \multirow[b]{2}{*}{ Variable } & \multicolumn{2}{|c|}{ Unstd. coeff. } & \multirow[b]{2}{*}{$\mathbf{t}$} & \multirow[b]{2}{*}{ Sig. } \\
\hline & & & regression & residual & & & & B & $\begin{array}{c}\text { Std. } \\
\text { error }\end{array}$ & & \\
\hline \multirow{5}{*}{$\mathrm{BIO}$} & \multirow{5}{*}{0.868} & \multirow{5}{*}{0.072} & \multirow{5}{*}{1.479} & \multirow{5}{*}{0.005} & \multirow{5}{*}{285.089} & \multirow{5}{*}{0.000} & (Constant) & 0.070 & 0.010 & 7.033 & 0.000 \\
\hline & & & & & & & $\mathrm{CR}$ & 0.462 & 0.016 & 29.238 & 0.000 \\
\hline & & & & & & & LR & 0.438 & 0.022 & 20.168 & 0.000 \\
\hline & & & & & & & OR & 0.438 & 0.029 & 15.330 & 0.000 \\
\hline & & & & & & & $\mathrm{BA}$ & 0.325 & 0.024 & 13.304 & 0.000 \\
\hline \multirow{5}{*}{ PH } & \multirow{5}{*}{0.817} & \multirow{5}{*}{0.073} & \multirow{5}{*}{1.220} & \multirow{5}{*}{0.005} & \multirow{5}{*}{227.008} & \multirow{5}{*}{0.000} & (Constant) & 0.044 & 0.007 & 6.459 & 0.000 \\
\hline & & & & & & & $\mathrm{CR}$ & 0.497 & 0.022 & 22.379 & 0.000 \\
\hline & & & & & & & LR & 0.487 & 0.029 & 16.533 & 0.000 \\
\hline & & & & & & & $\mathrm{BA}$ & 0.396 & 0.033 & 12.143 & 0.000 \\
\hline & & & & & & & $\mathrm{LC}$ & 0.391 & 0.049 & 8.044 & 0.000 \\
\hline \multirow{3}{*}{ HWOE } & \multirow{3}{*}{0.909} & \multirow{3}{*}{0.038} & \multirow{3}{*}{0.607} & \multirow{3}{*}{0.001} & \multirow{3}{*}{429.882} & \multirow{3}{*}{0.000} & (Constant) & 0.019 & 0.005 & 3.649 & 0.000 \\
\hline & & & & & & & $\mathrm{BA}$ & 0.484 & 0.017 & 28.277 & 0.000 \\
\hline & & & & & & & SA & 0.456 & 0.039 & 11.575 & 0.000 \\
\hline \multirow{4}{*}{$\mathrm{SC}$} & & & & & & & (Constant) & 0.021 & 0.004 & 4.905 & 0.000 \\
\hline & 0899 & 0050 & 1535 & 0002 & 618541 & 0000 & $\mathrm{BA}$ & 0.441 & 0.014 & 30.941 & 0.000 \\
\hline & 0.899 & 0.050 & 1.535 & 0.002 & 618.541 & & $\mathrm{LR}$ & 0.375 & 0.017 & 22.100 & 0.000 \\
\hline & & & & & & & SA & 0.491 & 0.029 & 17.111 & 0.000 \\
\hline & & & & & & & (Constant) & 0.027 & 0.006 & 4.374 & 0.000 \\
\hline & & & & & & & $\mathrm{BA}$ & 0.471 & 0.022 & 21.600 & 0.000 \\
\hline ILCE & 0.814 & 0.061 & 0.135 & 0.004 & 200.814 & 0.000 & $\mathrm{D}$ & 0.445 & 0.044 & 10.220 & 0.000 \\
\hline & & & & & & & $\mathrm{OC}$ & 0.418 & 0.049 & 8.530 & 0.000 \\
\hline
\end{tabular}

From the analysis of the open behaviours in the different segments, some observations can be made. First, the most widespread strategies are no doubt incorporation and inbound trading, both performed by more than half of the whole sample; yet, while separate additions do not have very high values of intensity, BCMAs ones are quite relevant for the whole sample. Yet, even if it is clear that BCMAs allow companies to acquire knowledge and technology from outside, it may be questionable whether it is correct to consider it as an "open" behaviour. BCMAs can be considered as hierarchy mechanisms but, if the innovation market were perfect, it would be possible to exchange innovation entities in separate acquisitions, with no need of BCMAs.

Actually, the companies for which incorporation is relevant do not usually show very high values of openness (e.g. in the technology hardware \& equipment industry), while if it is only one of the ancillary or exceptional strategy, highest degrees of openness are shown (e.g. in the bio-pharmaceutical industry).
We found that in the bio-pharmaceutical industry the most significant open transactions have an operational nature and, thus, for the companies in this industry, OI strategy is far more oriented to revenues and costs. These results are consistent with literature, which reports increasing trends of collaborative relationships between biotech and pharmaceutical companies in the last years (Hagedoorn and Roijakkers, 2002; Powell et al., 2005). As a matter of fact, large and long established pharmaceutical companies behave as innovation seekers acquiring R\&D services from small and young biotech firms (Powell et al., 1996). Conversely, as to technology hardware \& equipment industry, OI transactions are mainly financial and represented by goodwill; thus, in this industry BCMAs occur to acquire know-how and, therefore, goodwill can be effectively considered as a proxy of intellectual capital. This is consistent with literature, which reports know-how, technologies and capabilities as the valuable resources driving the recourse to BCMAs (Ahuja and Katila, 2001; Chaudhuri and Tabrizi, 1999). In particular, the 
incorporation strategy is a better solution for technology hardware \& equipment firms because of the modularity of IT design: many computer and chip designs are based on compatible independent components, and this makes it simpler to acquire readily integrated technology (Bower, 2001).

\section{Conclusion}

The paper examines the business models adopted by companies in order to embrace the OI paradigm: collaboration, outsourcing, licensing, trading and incorporation. The work is based on the analysis of consolidated annual reports of 271 R\&D intense companies operating in bio-pharmaceutical and technology hardware \& equipment industries: open costs and revenues, new investments and divestments of intangibles are analysed for the three years period 2010-2012. In the bio-pharmaceutical industry outbound strategies based on open revenues are very frequent, with higher intensity in the biotechnology segment than in the pharmaceutical one; within technology hardware \& equipment companies, the most characterizing strategy is the inbound incorporation of other firms. Through this analysis, both the framework applicability and its explicative power and usefulness were validated.

The paper addresses the need for operative, practical instruments, which can help managers to monitor and control their innovation strategies after an openoriented approach. Given the availability and objectivity of annual report figures, defining OI models through the analysis of financial statements can help decisionmakers to assess the status of their own open strategies and compare it over time and space, also allowing the benchmarking with competitors.

\section{References}

1. Ahuja, G. and Katila, R. (2001), 'Technological acquisitions and the innovation performance of acquiring firms: a longitudinal study,' Strategic Management Journal, 22 (3), 197-220.
2. Barge-Gil, A. (2010), 'Open, semi-open and closed innovators: towards an explanation of degree of openness,' Industry and Innovation, 17 (6), 577-607.

3. Bianchi, M., Cavaliere, A., Chiaroni, D., Frattini, F. and Chiesa, V. (2011), 'Organisational modes for open innovation in the bio-pharmaceutical industry: an exploratory analysis,' Technovation, 31 (1), 22-33.

4. Boekestein, B. (2009), 'Acquisitions reveal the hidden intellectual capital of pharmaceutical companies,' Journal of Intellectual Capital, 10 (3), 389-400.

5. Bower, J.L. (2001), 'Not all M\&As are alike - and that matters,' Harvard Business Review, 79 (3), 93-101.

6. Brännström, D., Catasús, B., Gröjer, J.-E. and Giuliani, M. (2009), 'Construction of intellectual capital - the case of purchase analysis,' Journal of Human Resource Costing \& Accounting, 13 (1), 61-76.

7. Chaudhuri, S. and Tabrizi, B. (1999), 'Capturing the real value in high-tech acquisitions,' Harvard Business Review, 77 (5), 123-130.

8. Cheng, C.C.J. and Huizingh, E.K.R.E. (2014), 'When is open innovation beneficial? The role of strategic orientation,' Journal of Product Innovation Management, 31 (5), 1-19.

9. Chesbrough, H. (2003) Open Innovation: The New Imperative for Creating and Profiting from Technology, Harvard Business School Press, Boston.

10.Dahlander, L. and Gann, D.M. (2010), 'How open is innovation?,' Research Policy, 39 (6), 699-709.

11.Gassmann, O. and Enkel, E. (2004), 'Towards a theory of open innovation: three core process archetypes'. Proceedings of the R\&D Management Conference. 6-9 July 2004. Lisbon, Portugal.

12.Gianiodis, P., Ellis, S.C. and Secchi, E. (2010), 'Advancing a typology of open innovation,' International Journal of Innovation Management, 14 (4), 531-572. 
13.Hagedoorn, J. and Roijakkers, N. (2002), 'Small entrepreneurial firms and large companies in inter-firm R\&D networks the international biotechnology industry'. In Hitt, M., Ireland, R., Camp, S. and Sexton, D. (eds.), Strategic Entrepreneurship: Creating a New Integrated Mindset, Blackwell, Oxford, 223-252.

14.Hung, K.P. and Chiang, Y.H. (2010), 'Open innovation proclivity, entrepreneurial orientation, and perceived firm performance,' International Journal of Technology Management, 52 (3-4), 257274.

15.Idrissia, M.O., Amaraa, N. and Landrya, R. (2012), 'SMEs' degree of openness: The case of manufacturing industries,' Journal of Technology Management and Innovation, 7 (1), 186-210.

16.Keupp, M.M. and Gassmann, O. (2009), 'Determinants and archetype users of open innovation,' R\&D Management, 39 (4), 331341.

17.Kim, H. and Park, Y. (2010), 'The effects of open innovation activity on performance of SMEs: the case of Korea,' International Journal of Technology Management, 52 (34), 236-256.

18.Laursen, K. and Salter, A. (2006), 'Open for innovation: the role of openness in explaining innovation performance among U.K. manufacturing firms,' Strategic Management Journal, 27 (2), 131-150.

19.Lazzarotti, V. and Manzini, R. (2009), 'Different modes of open innovation: A theoretical framework and an empirical study,' International Journal of Innovation Management, 13 (4), 615-636.

20.Michelino, F., Lamberti, E., Cammarano, A. and Caputo, M., (2014), 'Measuring open innovation in the bio-pharmaceutical industry,' Creativity and Innovation Management, 23 (4), 1-25.

21.Parida, V., Westerberg, M. and Frishammar, J. (2012), 'Inbound Open Innovation Activities in High-Tech SMEs: The Impact on Innovation Performance,' Journal of Small Business Management, 50 (2), 283-309.
22.Podmetina, D., Väätänen, J., Torkkeli, M.T. and Smirnova, M.M. (2011), 'Open innovation in Russian firms: an empirical investigation of technology commercialisation and acquisition,' International Journal of Business Innovation and Research, 5 (3), 298-317.

23.Powell, W., Koput, K. and Smith-Doerr, L. (1996), 'Interorganizational collaboration and the locus of innovation: networks of learning in biotechnology,' Administrative Science Quarterly, 41 (1), 116-145.

24.Powell, W., White, D., Koput, K. and Owen-Smith, J. (2005), 'Network dynamics and field evolution: The growth of interorganizational collaboration in the life sciences,' American Journal of Sociology, 110 (4), 1132-1205.

25.Santamaria, L., Nieto, M.J. and Barge-Gil, A. (2010), 'The Relevance of Different Open Innovation Strategies for R\&D Performers,' Cuadernos de Economía y Dirección de la Empresa, 13 (45), 93-114.

26.Schroll, A. and Mild, A. (2011), 'Open innovation modes and the role of internal R\&D: An empirical study on open innovation adoption in Europe,' European Journal of Innovation Management, 14 (4), 475-495.

27.Spithoven, A. (2013), 'Open innovation practices and innovative performances: An international comparative perspective,' International Journal of Technology Management, 62 (1), 1-34.

28.Teirlinck, P. and Poelmans, E. (2012), 'Open innovation and firm performance in small-sized R\&D active companies in the chemical industry: the case of Belgium,' Journal of Business Chemistry, 9 (3), 117 132.

29.Teirlinck, P. and Spithoven, A. (2008), 'The spatial organization of innovation: open innovation, external knowledge relations and urban structure,' Regional Studies, 42 (5), 689-704.

30.Tranekjer, T.L. and Knudsen, M.P. (2012), 'The (Unknown) Providers to Other 
Firms' New Product Development: What's in It for Them?,' Journal of Product Innovation Management, 29 (6), 986-999.

31.van de Vrande, V., de Jong, J.P.J., Vanhaverbeke, W. and de Rochemont, M.
(2009), 'Open Innovation in SMEs: Trends, Motives and Management Challenges,' Technovation, 29 (6-7), 423-437 